\title{
INTERLENDING AND DOCUMENT SUPPLY IN THE CONTEXT OF SPANISH LIBRARY CONSORTIA
}

\author{
Mercedes Echeverría and Sonsoles Jiménez
}

\begin{abstract}
Purpose - The paper's aim is to provide insights into interlending and document supply (ILDS) practices in Spain in the current environment of library consortia and to present recent trends in academic ILDS services.

Design/methodology/approach - An overview of the Spanish library system is provided followed by a more detailed look at cooperation generally and interlending and document supply specifically. Finally a survey of researchers and their use of e-journals and alternative methods of access in a medical library.

Findings - After some years of decline interlending and document supply is experiencing modest increases. Some interesting results from the survey on the tolerance to use document supply instead of low use journals are found.

Value - The paper presents a current overview of the situation in Spain for library cooperation, interlending and document supply
\end{abstract}

Keywords - Consortia, Big Deals, Journal usage, Interlending, Libraries, Spain

Paper type - General review

\section{INTRODUCTION}

The purpose of this paper is to provide insights into interlending and document supply (ILDS) practices in Spain in the current environment of library consortia and to present recent trends in academic ILDS services.

The first section, provides an overview of universities within the Spanish politicaladministrative system of autonomous communities. The second looks at cooperation among libraries and describes the origins of library consortia, their organization and activities. The third, analyses the ILDS services provided in Spain in the period 2005/2009, focusing on the role of consortia. This section describes also includes the results of a small survey on practices used by researchers for information recovery and their perceptions of ILDS services as a substitute for e-journal access.

\section{BACKGROUND}

The origin of the current political-administrative structure of Spain is in the Constitution of 1978, which transformed a deeply centralized state by decentralizing it into 17 regions or autonomous communities.

The Spanish higher education system comprises 50 public and 27 private universities. Except for two universities that are state owned ${ }^{1}$, all the others are dependent on the autonomous communities (España. Ministerio de Educación, 2011). The public universities are selfgoverning and are regulated by the Universities Act (2001). These universities have their own budget which is mainly funded by the regional government and partially by the national budget. In practice, as (Pacios and Repiso, 2010, p. 353) explain "the Spanish university system is really 17 systems that operate autonomously and are coordinated through the State University Coordination Council"

\footnotetext{
${ }^{1}$ UNED and Universidad Internacional Menéndez Pelayo

Interlending and document supply in the context of Spanish library consortia
} 


\subsection{A few facts about Spanish universities}

The gradual increase in the number of university students has slowed down in the last ten years, mainly due to a drop in the birth rate and strong economic development. According to the report (España. Ministerio de Educación, 2011, p. 9) since the academic year 1999/2000, when 1.589,000 students were enrolled in Spanish universities, their numbers have fallen by 11 per cent to $1,377,228$ in $2008 / 2009$. However, in the $2009 / 2010$ academic year numbers increased again by 2 per cent.

In contrast, the number of academic staff and researchers in public universities increased sharply by 44 per cent over the period 1996/2008, reaching 107,930 in 2008/2009. (Conferencia de Rectores de las Universidades Españolas, 2010, p. 34)

Spanish scientific production doubled during the period 1998/2008, from 25,560 publications (1998) to 52,596 (2008). The percentage of publications written with international collaboration in the same period grew steadily to reach 42 per cent of all publications. Furthermore, the proportion of Spanish scientific production, both in Europe and worldwide, has maintained an upward trend reaching 10 and 3 per cent respectively in 2008 (España. Ministerio de Educación, 2011 p. 90).

\section{LIBRARY COOPERATION IN SPAIN}

\subsection{A short history}

Library cooperation in Spain began seriously in the early 1980s and was first structured around the specialized libraries belonging to universities, hospitals and professional university colleges. Cooperation between biomedical libraries created the 'Coordinadora de Documentación Biomédica' (1983). Mathematical libraries created 'Documat' (1988) and later, in 1995 the Association of Engineering Libraries 'MECANO' came into being. The main objectives of these efforts were focused on the creation of union catalogues and providing ILDS services.

At the end of the 1980s libraries faced a number of challenges, such as changes in management, the automation of catalogue processes and the implementation of new library systems. As a consequence, the specialized library associations were weakened (Anglada 2003 p. 2). In response to these changes a second group of entities emerged based on library management systems, such as 'VTLS', 'Ruedo' for Dobis/Libis' users, 'The Libertas Group', and 'Rueca' for Absys' users, whose main objective was to produce union catalogues for libraries sharing the same software.

In this period, cooperation was achieved nationally with the creation of the Spanish Network of University Libraries (Rebiun) in 1988 by a group of academic library directors. The first objective of Rebiun was to set up a stable organization whose activities concentrated on developing ILDS services and publishing a union catalogue for university libraries in CDROM format. Furthermore, Rebiun emphasized its interest in improving library infrastructures and technical services to encouraged cooperation.

\subsection{Spanish library consortia: origin and overview}

The existence of library consortia is a recent phenomenon that began to flourish in the last ten years involving libraries worldwide. The first Spanish library consortium, called CBUC, was founded in 1996 in the autonomous community of Cataluña. Its members are eight public 
Catalonian universities and the Library of Cataluña ${ }^{2}$. Two years later, in 1999, the library consortium of the autonomous community of Madrid, called Madroño ${ }^{3}$, was established, consisting of six public universities and UNED, the Open University. In 2001, two new consortia were created, one in the autonomous community of Galicia, called BUGalicia ${ }^{4}$, made up of three public universities, and the other, $\mathrm{CBUA}^{5}$, bringing together ten public universities of the autonomous community of Andalucia. Finally, in 2002 the consortium of the autonomous community of Castilla-León, called BUCLE ${ }^{6}$, was created, consisting of four public universities.
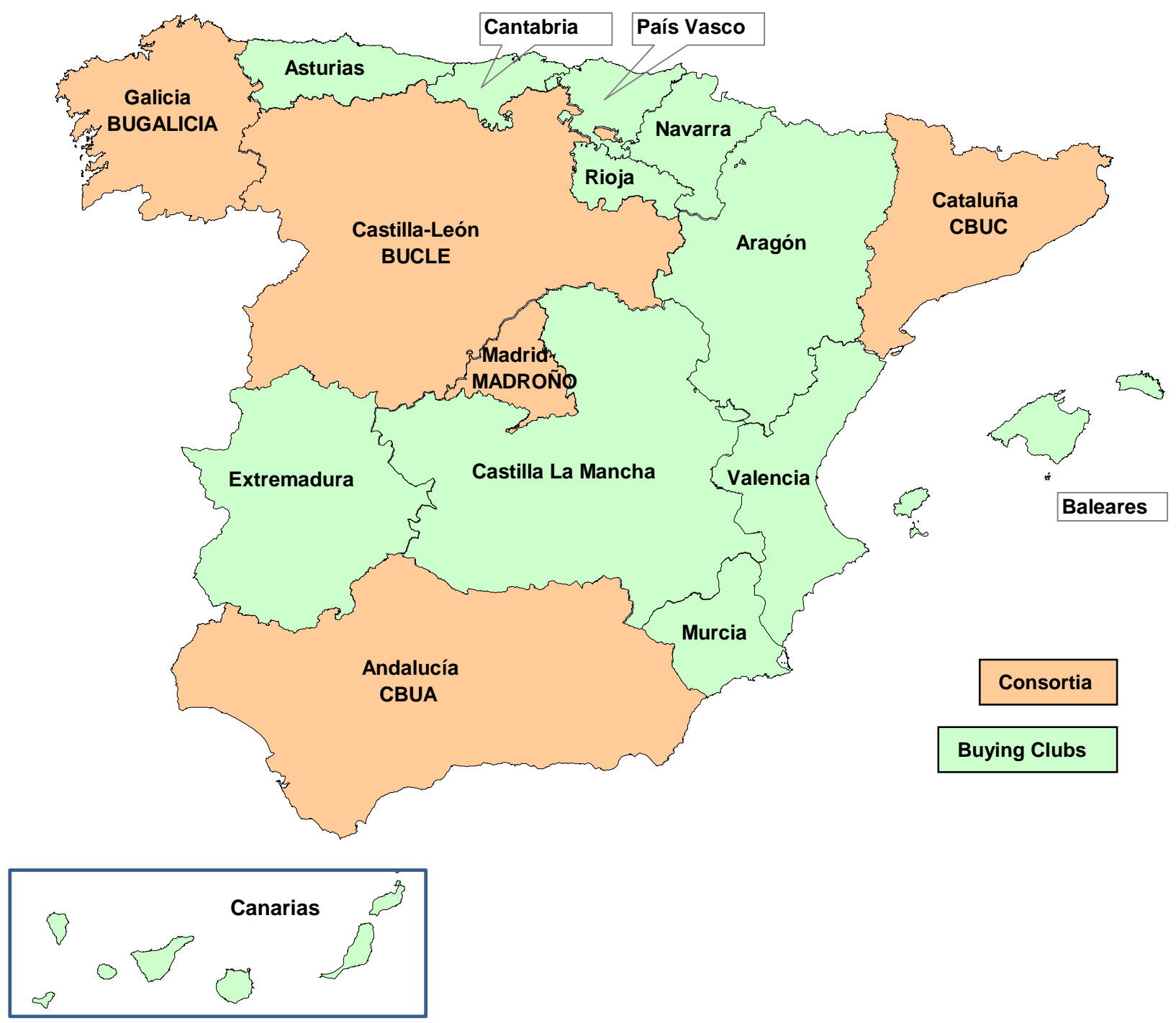

Figure 1: Map of Spanish consortia and buying clubs

Overall, 32 universities have joined consortia, comprising 64 per cent of all Spanish public universities. They included 60 per cent of Spanish graduate students in the academic year 2008/2009. (Conferencia de Rectores de las Universidades Españolas, 2010, p. 31).

The Spanish consortia are characterized by a cooperative regional model structured within the political context of autonomous communities. These consortia are entities with legal

\footnotetext{
${ }^{2}$ CBUC. Available at: http://www.cbuc.cat/ (Accessed 6 May 2011)

${ }^{3}$ Madroño. Available at: http://www.consorciomadrono.es/ (Accessed 6 May 2011)

${ }^{4}$ BUGalicia. Available at: http://www.bugalicia.org/ (Accessed 6 May 2011)

${ }^{5}$ CBUA. Available at: http://www.cbua.es/ (Accessed 6 May 2011)

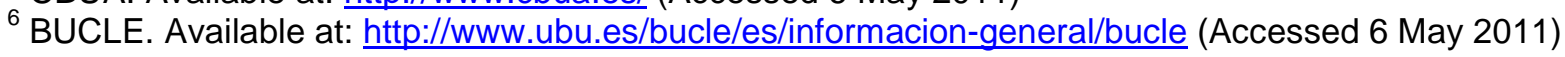
Interlending and document supply in the context of Spanish library consortia
} 
personality. Their funding comes from membership fees (between 63 and 85 per cent), and from the autonomous communities (15 to 37 per cent) (Abad Hiraldo and Anglada, 2010, p. 18). An analysis of the regional distribution of Spanish consortia shows that out of the 17 autonomous communities that make up Spain:

- Five communities have library consortia which correspond to regions with several universities and a multi-provincial structure: Cataluña, Galicia, Andalucía and CastillaLeón. Among them, Madrid is the only region with a single province but it has six public universities and UNED.

- $\quad$ Six of the ten remaining autonomous communities ${ }^{7}$, consist of a single province ${ }^{8}$, and the other four are multi-provincial but with only one university 9 .

- Two communities, Valencia and Canarias, have multi-provincial structures and support several public universities each but they have not yet been able to create consortia of their own.

This overview shows that there are at least ten autonomous communities comprising one province or maintaining a single university that cannot create a consortium.

Those universities that are unable to form a consortium have chosen the alternative model known as 'buying clubs', such as "Grupo G-9" and the "Club de compra Canarias-Levante".

\subsection{Consortia: objectives and activities}

The basic characteristics of a consortium are management planning, pooled resources for development and shared responsibility among its members. That means that without either organization, resources or collaboration it is impossible to get results. Nobody would assume that a national cancer program could be successful with just a few hospitals working on a voluntary basis.

All Spanish consortia acknowledge among their objectives the improvement of the quality of library services through cooperation. At this juncture, it is interesting to analyse how the cooperative initiatives of the consortia have evolved over time.

In the mid-1990s the first consortium initiatives were linked to the acquisition of library management systems. The joint acquisition of the same software was the basis of consortia such as: CBUA (Innopac Millennium), CBUC (VTLS), BUCLE (Innopac Millennium) and Madroño (Unicorn). Indeed, two of these consortia, CBUC and BUGalicia were supported by regional computer centres. The new library technology created the basis for cooperative projects focused on the development of union catalogues. These catalogues, using international standards, improved access to information, allowed the sharing of collections and resources, reduced the costs of cataloguing and improved ILDS arrangements.

Although sharing resources is an essential aspect of consortia, the object of sharing has changed over time. In the early 2000s, new factors motivated cooperation, such as the emergence of e-journals, economic changes that reduced funding to higher education and the rising cost of scholarly publications. During this period, the main objective of most consortia, as (Giordano, 2002 , p. 1) points out, was "to offer users wide access to electronic information resources on terms acceptable to libraries, enabling the latter to achieve economies of scale and improve their services".

\footnotetext{
${ }^{7}$ Autonomous communities of: Aragón, Asturias, Cantabria, Castilla-La Mancha, Extremadura, Islas Baleares, Rioja, Murcia, Navarra and País Vasco.

${ }^{8}$ Autonomous communities of: Asturias, Islas Baleares, Cantabria, Rioja, Navarra and Murcia.

${ }^{9}$ Autonomous communities of: Extremadura and País Vasco.

Interlending and document supply in the context of Spanish library consortia
} 
However, consortia are not only an instrument for purchasing information but also an important transformational tool for innovative library practices (Térmens, 2008, p. 77). In this regard, Spanish consortia have been involved in new projects such as:

- BUCLE which uses OCLC WorldCat Local as its search interface. This program allows library users not only to access the library's local bibliographic records but also titles from the entire BUCLE group's catalogues and from the OCLC WorldCat database.

- CBUA has implemented the software INN-Reach, version webPAC Pro, to support their union catalogue providing transactions between consortium libraries. The program is integrated with the circulation module.

-CBUC's Encore project is integrated with Innopac Milennium, which brings collections into a single discovery environment. The purpose is to maximise the use of the consortium's collections without the need for maintenance by CBUC or local staff. This project is integrated with the circulation module and therefore such transactions are removed from the ILDS module.

\subsection{Buying clubs}

Public universities that are unique within their regions chose an alternative model known as the 'buying clubs' founding in 1997 know as "Grupo-7". By 2003 two more universities from multiprovincial regions, joined, turning the buying club into "Grupo-9"10 11. Additionally, in 2001 the "Club de compra Canarias-Levante" was set up by universities of these regions.

The buying clubs are characterised by an open structure, allowing institutions to select which resources to buy and with whom. They operate as consortia only for the purpose of exploiting economies of scale when purchasing electronic resources. Their activities are heterogeneous and cover different areas, from the mobility of students between universities to interlibrary loan arrangements. However, they lack the tools to transform library services into cooperative services. Fundamentally, they lack legal support and unlike consortia, do not receive institutional and funding support. The buying clubs only work together during specific projects. They do not have a solid structure that would allow them to negotiate with publishers through a central negotiation body instead, individual libraries decide whether they will opt into each deal separately. Overall, the buying clubs focus specifically on cooperative negotiation for e-journals acquisitions.

\section{RESOURCE SHARING: BIG DEALS}

The traditional subscriptions of individual journal titles were replaced during the 2000s by a new type of purchasing model aimed at achieving economies of scale known as 'Big Deals'. Big Deals are licensing agreements for packages of e-journals in which a library or consortium might access the complete publisher's catalogue but on condition that it is not able to eliminate or cancel journals during the period of the agreement.

\subsection{Figures for the 'Big Deals'}

Ulrich's International Periodical Directory gives information on over 300,000 titles, 60,000 of which are current and about 25,000 of these comprise the 'core' of scholarly currently published research titles, most of the current issues of which are available electronically, (McGrath 2009, p. 2).

Although it is difficult to estimate the real number of e-journals available via 'Big Deals' because of the wide variation in publisher packages, more than 8,500 journal titles are currently

\footnotetext{
${ }^{10}$ Grupo-9 consisted of universities from: Cantabria, Castilla La Mancha, Extremadura, Islas Baleares, Rioja, País Vasco, Universidad Pública de Navarra and University of Zaragoza.

${ }_{11}$ Grupo-9. Available at: http://www.uni-g9.net/portal/index.jsp (Accessed 15 July 2011)

Interlending and document supply in the context of Spanish library consortia
} 
available mostly from major commercial publishers (Table 1). That means that five publishers produced about 34 per cent of the core titles. This percentage corresponds with Turner's estimate of 2004 that "five publishers produced 5000 journals (33 per cent). [Consequently] 66 per cent of scholarly journals were outside 'Big Deals", (Turner, 2005, p. 218).

\begin{tabular}{|l|l|}
\hline Publishers & Journal Titles \\
\hline Elsevier $^{12}$ & 2,599 \\
\hline Springer $^{13}$ & 2,400 \\
\hline Wiley $^{14}$ & 1,500 \\
\hline Taylor \& Francis $^{15}$ & 1,500 \\
\hline Sage $^{16}$ & 630 \\
\hline Total & $\mathbf{8 , 5 5 9}$ \\
\hline
\end{tabular}

Table1: Major publishers of peer-reviewed journals (2011)

In addition, an analysis of the production of the three highest ranked publishers for the period 2006/2011, reveals that they have expanded their business, from 4,030 journals in 2006 to 6,429 in 2011 (Table 2).

\begin{tabular}{|l|c|c|c|}
\hline Publisher & Journals in 2006 $^{\mathbf{1 7}}$ & Journals in 2011 & Percentage \\
\hline Elsevier & 2,199 & 2,529 & 15 \\
\hline Springer & 1,293 & 2,400 & 86 \\
\hline Wiley & 538 & 1,500 & 179 \\
\hline Total & 4,030 & 6,429 & 60 \\
\hline
\end{tabular}

Table 2: Figures of major publishers of 'Big Deals’ (2006-2011)

The market is moving towards a higher concentration where a few publishers are marginalising smaller publishers as the 'Big Deals' take more and more of library budgets.

\subsection{The 'Big Deals' in times of economic crisis}

According to the analysis of (Fernández-Villaverde and Ohanian, 2010, p. 3), since the summer of 2007 international financial markets have suffered from a soaring volatility, increasing risk and generalized disruptions in secondary markets. The collapse of institutions such as Lehman Brothers has forced government interventions and the collapse of investment banking. Spain is experiencing its worse crisis since the1970s.

The impact of economic crisis has forced libraries to cancel journals that were previously thought of as untouchable, in many cases, in order to find the finance for the consortia purchasing agreements for e-journals.

\footnotetext{
${ }^{12}$ Elsevier (2011) Available at: http://www.elsevier.com/wps/find/journal browse.cws home (Accessed 2 June 2011)

${ }^{13}$ Springer (2011). Available at: http://www.springer.com/librarians/e-content/journals?SGWID $=0$ 170902-12-460499-0. (Accessed 2 June 2011)

${ }^{14}$ Wiley (2011). Available at: http://olabout.wiley.com/WileyCDA/Section/id-404513.html (Accessed 2 June 2011)

${ }^{15}$ Taylor \& Francis: Available at: http://www.taylorandfrancisgroup.com/ (Accessed 2 June 2011)

${ }_{17}^{16}$ Sage (2011). Available at; http://www.sagepub.com/journals.nav (Accessed 2 June 2011)

${ }^{17}$ Térmens, M. (2007) La cooperació bibliotecària en l'era digital. Consorcis i adquisitions de revistes a les biblioteques universitàries catalanes [thesis]. Barcelona : Universitat de Barcelona. Available at: http://hdl.handle.net/10760/10813 (Accessed 20 April 2011), p. 224

Interlending and document supply in the context of Spanish library consortia 
Clearly, the combination of funding cuts and the increase of serials prices is detrimental to library collections. With budgets down and serials prices continuing to rise above the CPI inflation by 4 or 5 per cent, it becomes hard to maintain existing journal subscriptions. So libraries are forced to cut budgets not only for journals but also for books and indeed databases, without being able to solve the problem.

Six years ago, (Frazier, 2005, p. 51) pointed out that "Big Deals are not sustainable". The recent problems libraries have in renewing licences as well as the multiple cancellations are symptoms of this business model breaking down. The 'Big Deal' is based on the presumption that libraries can always increase expenditures and that publishers must constantly increase revenues. So far, the consortia agreements have been made possible by extra funding from the public administration and by cuts in library commodities. Currently, the strategy taken by Spanish consortia consists of extending participation in the consortium to other partners. In this regard we can mention:

--The BUCLE Consortium has considered making contacts with other consortia to carry out collaborative activities (Martín Rodríguez, 2010, p. 78).

-The BUGalicia Consortium has been widened to other Galician institutions, such as SERGAS (Galician Health Service) with the aim of optimising the resources (Millor Rego 2010, p. 52).

-The CBUA Consortium plans a close collaboration on procurement of e-content with other Spanish consortia and buying clubs, (Baena Díaz, 2010, 66).

-A new project of the CBUC Consortium pursuing agreements with hospitals and research centres in order to obtain funding and a larger critical mass of publications, (Anglada et al. 2010, p.31).

-The Madroño Consortium intends to establish alliances, as an essential tool to overcome the current economic context, with universities, foundations and other organizations, and more recently they are negotiating with the Committee of the Health Library "Lain Entralgo", (López Ortiz de Artiñano 2010, p. 48).

Therefore, in the current economic environment, the strategy followed by three of the five Spanish consortia (BUGalicia, CBUC and Madroño) is to expand alliances mainly to libraries of regional health services. In this way they hope to improve their negotiating power to achieve more favourable licensing terms and also avoid journal subscription duplications within the same region.

\subsection{The 'Big Deals' and journal usage}

Unfortunately, the confidentiality clause in agreements with publishers limits the amount of useful data available to libraries, (Bevan et al. 2005, p. 116). The confidentiality policy is in strong contrasts with the essential transparency needed to assess information resources and which is also required by the public administration.

In Spain the only systematic studies for collecting statistics on journal usage have been done by the CBUC Consortium. The first CBUC study was published by Urbano et al, 2004. This article analysed the use of electronic journals licensed by the CBUC during 2000/2003. This period covers the change from paper to digital format of the CBUC collections.

The use of titles previously not subscribed was very high at 61 per cent of total usage. There was also a considerable concentration of use in certain titles: 80 per cent of the articles downloaded were from 516 journals out of 1,498 , which means that the core consumption was satisfied by 34 per cent of the titles.

Three years later, (Térmens 2007) devoted a chapter of his doctoral thesis to analysing the electronic journals usage at the CBUC Consortium. In 2006, the year of data analysis, the Interlending and document supply in the context of Spanish library consortia 
transition to 'e' was complete and widely accepted by researchers. The study analysed the usage of 5,139 titles. The degree of concentration was such that 80 per cent of journal usage was satisfied by 1,309 titles ( 25 per cent) 476 being from Big Deals. In addition, 5 per cent of the articles accessed came from 3,089 titles, (61 per cent), 2,194 titles being from Big Deals. Therefore, among journals not previously subscribed and acquired as Big Deals:

11 per cent of the titles were highly used ( 80 per cent of total accesses) 19 per cent were of average use ( 15 per cent of total accesses) and 72 per cent were low use journals ( 5 per cent of total accesses).

Finally, in 2010, (Anglada et al 2010, p. 31) noted that 60 per cent of articles downloaded at the CBUC were from Big Deal purchased journals.

Overall, these data seem to show that the increase in digital information access fosters overall use although the usage patterns of journals acquired as part of Big Deals shows a high dispersion and a low degree of concentration.

\subsection{Purchasing of Big Deals}

Since Spanish consortia are based on regional autonomies the political administrative organization could cause certain imbalances between regions. Therefore, one of the roles of central government should be to ensure a balance between Spanish regions.

In 2006 the Becyt's project (Biblioteca Electronica de Ciencia y Tecnología) was presented with the proposal to create a framework for purchasing e-journals for all Spanish universities, research centres and national health service libraries; reasoning that the government should ensure fair access to scientific information for all academic staff and students. The Becyt's project was based on funding collaboration between autonomous communities, central government and institutions which used the resources. However, the first serious initiative to implement national licences failed because of disagreement over economic issues and the removal of the Education minister. So far, the only research resources acquired as national licenses have been 'Web of Knowledge' since 2004 and 'Scierve Scopus' since 2010 by Fecyt (Fundación Española para la Ciencia y la Tecnología).

It would be appropriate here to describe briefly the purchasing strategies for electronic resources adopted by European countries close to Spain through national licences:

- In France (Schöpfel and Gillet, 2011, p. 78) notes that under the French LRU law of 2007 universities moved from centralised administration towards greater autonomy. Indeed, currently most French universities are involved in reorganization and mergers into local or regional consortia. In this context the author points out that "In 2010 COUPERIN together with the Ministry of Higher Education and public research organizations opted for national licences for multidisciplinary and generalist digital collections (such as Science Direct and Springerlink), together with backfiles and databases (Web of Science, Scopus)".

- In Germany, a decentralised country like Spain, (Rosemann and Brammer, 2010, p.29) explains that "Since 2004, two principal licensing models have been tested in the context of the National Licences funded by the German Research Foundation. On the one hand, the so-called 'classic model' of national licences, and on the other a participation model which is still in its pilot phase and is currently undergoing further development. Under the classic model, 100 per cent of the funding is provided by DFG and the licensed content can be made accessible to all publicly owned scientific institutions in Germany". 
- In the United Kingdom, NESLi2, the national initiative for licensing online journals on behalf of the higher education and research communities in the UK, published data showing efficiency gains on licensing agreements. In 2007/2008 gains amounted to $£ 7$ million (JISC, 2009) and in 2009/2010 the licensing activity savings exceeded $£ 13$ million (JISC Collections, 2011, p. 4).

\section{SPANISH INTERLIBRARY LOAN}

Traditionally ILDS services have played an important role in library cooperation and research support. Since 1989, Rebiun (The Spanish Academic Libraries Network) has been responsible for the coordination and enhancement of ILDS services for university libraries in Spain through the 'Interlibrary Loan Working Group'. Furthermore, in line with IFLA standards, Rebiun has also tried to establish common criteria, normalise processes and raise the quality of ILDS practices nationwide. To further its goals in 2008, Rebiun published its 'Manual de procedimiento de préstamo interbibliotecario' [The Interlibrary loan procedures manual], (Rebiun, 2008), a document outlining good practices for coordination, management and statistical purposes.

\subsection{Recent trends in interlibrary loans}

Since 2000 there have been two main trends in ILDS services. Firstly, from 2000 to 2005, there was a decline of 23 per cent in transactions. The introduction of e-journals in 2000 marked a turning point, with a significant decrease of ILDS over the next four years, as shown in Figure 2. Secondly, 2005 to 2009 saw a rise of 8 per cent in the number of transactions generated. Since 2008, the number of ILDS transactions has stabilised and even shows a slight recovery. The figures are based on 'Consultas y cálculos sobre datos e indicadores de las bibliotecas' [Statistical performance indicators], (Rebiun. 2009).

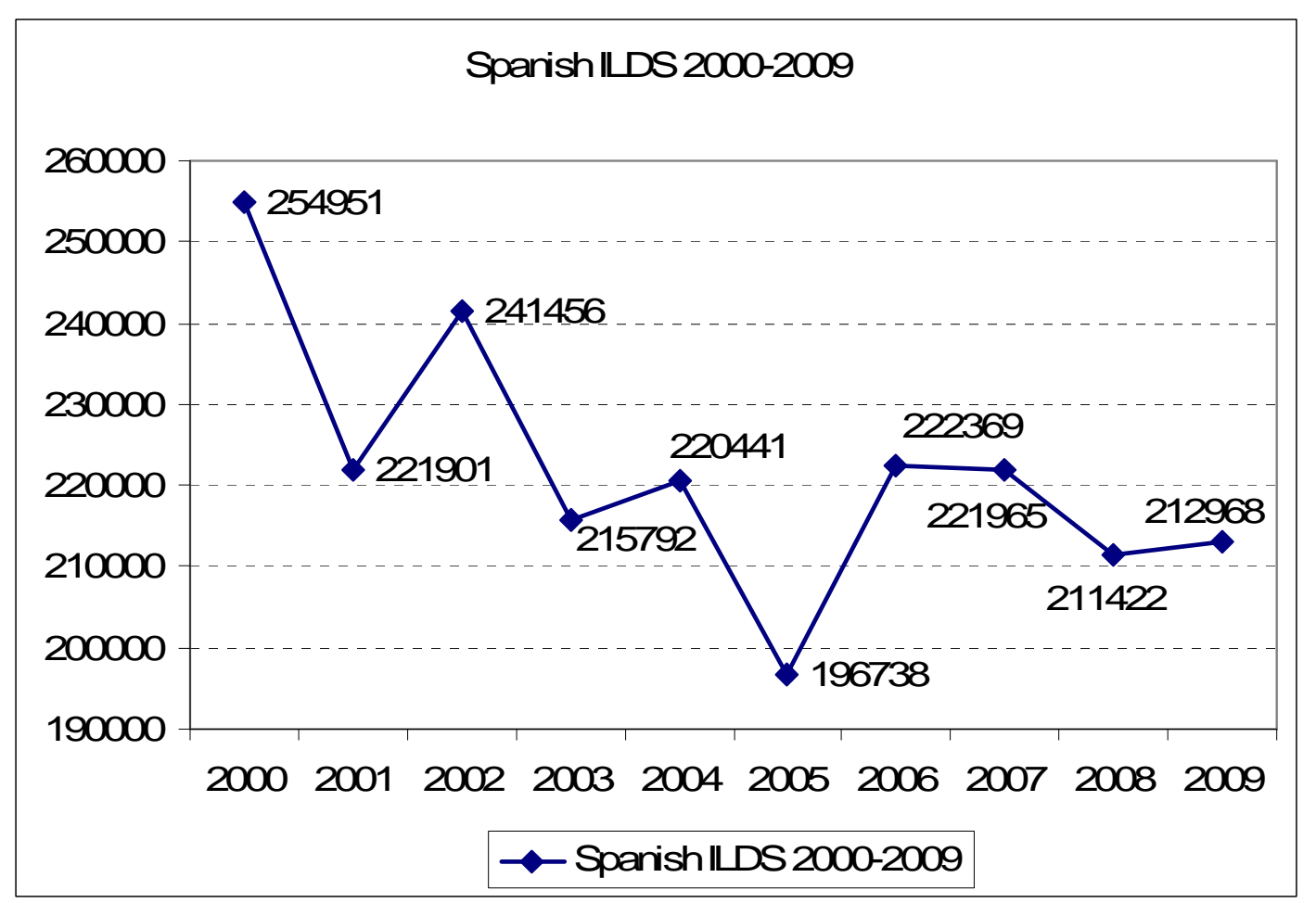

Figure 2: Spanish ILDS between 2000-2009 


\subsection{Requests by type}

Historically, the ratio of article copies to loan requests has always favoured copies. In the period $2000 / 2005$, at a time when the impact of e-journals was growing, loan requests represented 30 per cent of transactions. However, over time this figure has been changing, with a constant increase in loan requests. The period 2005/2009 reflects greater convergence between loans and copies with a 14 per cent rise in loans, as shown in Figure 3.

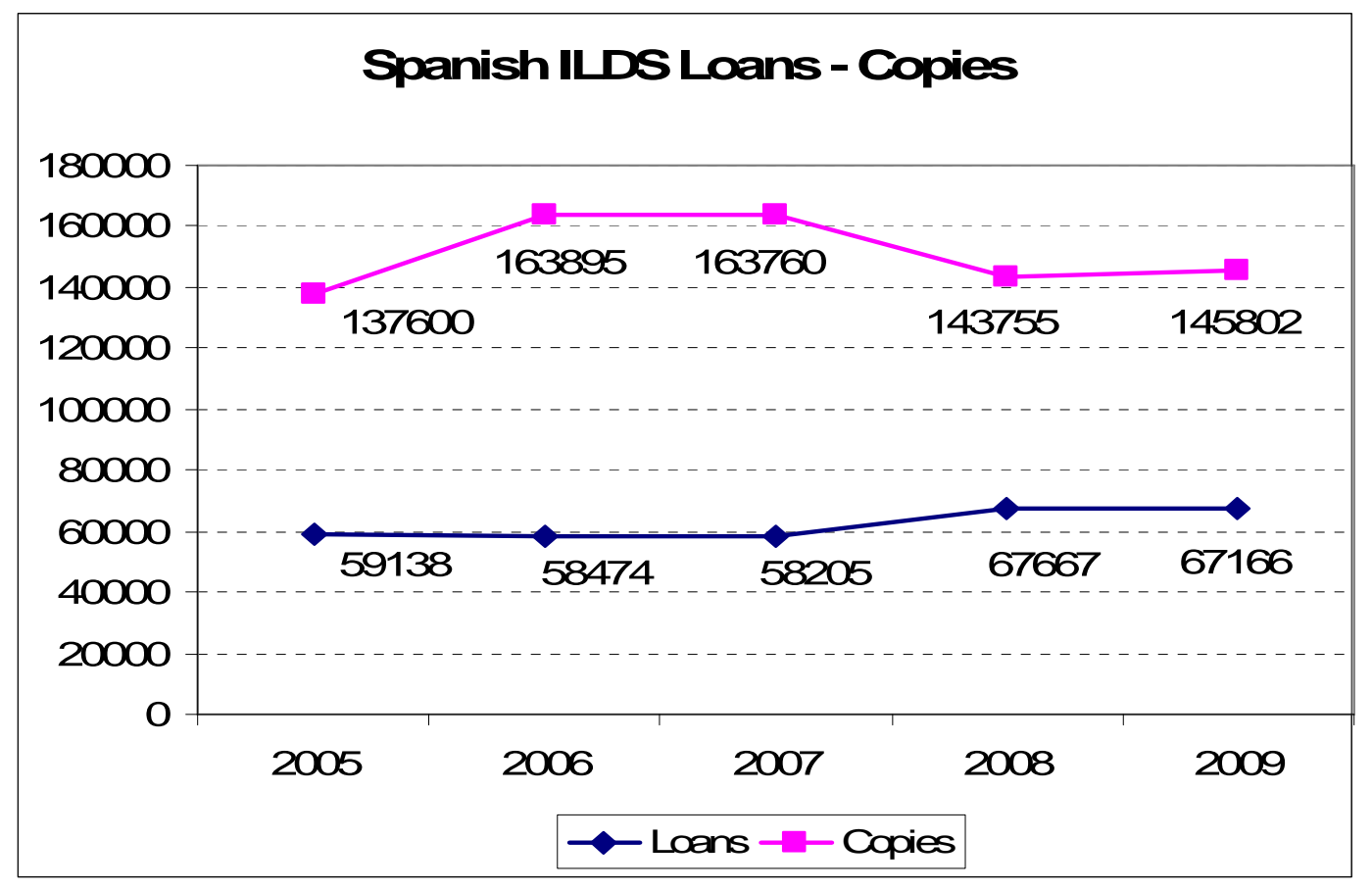

Figure 3: Spanish loans and copies requests (2005-2009)

\subsection{Interloan requests and consortia}

Between 2005 and 2009, 72 per cent of all national loan requests were by consortia ${ }^{18}$ as shown in Table 3. This large proportion could be due to internal loan transactions between libraries of the same consortium were counted in the ILL module. However, these figures are likely to change in the future because of the introduction of new policies by some of Spanish consortia to integrate the loan requests from libraries of the same consortium into the circulation module instead of the ILL module

\begin{tabular}{|r|r|r|}
\hline \multicolumn{1}{|l|}{ Years } & Rebiun - Loans & \multicolumn{2}{|c|}{$\begin{array}{l}\text { Consortia - } \\
\text { Loans }\end{array}$} \\
\hline 2005 & 59138 & 43052 \\
\hline 2006 & 58474 & 42385 \\
\hline 2007 & 58205 & 42409 \\
\hline 2008 & 67667 & 48853 \\
\hline 2009 & 67166 & 48440 \\
\hline TOTAL & $\mathbf{3 1 0 6 5 0}$ & $\mathbf{2 2 5 1 3 9}$ \\
\hline
\end{tabular}

Table 3: Rebiun (Spanish Academic Libraries Network) loans and consortia loans (2005-2009)

\footnotetext{
${ }^{18}$ There are no data available that can discriminate loans within libraries of the same consortium and loans with other libraries outside a consortium.

Interlending and document supply in the context of Spanish library consortia
} 


\subsection{Copy requests and consortia}

There was an increase of 6 per cent in copy requests during 2005/2009. Consortia supplied just over half of these copies for Spanish academic libraries, as shown by Table 4.

\begin{tabular}{|r|r|r|r|}
\hline Years & \multicolumn{1}{|c|}{$\begin{array}{c}\text { Rebiun - Copy } \\
\text { requests }\end{array}$} & $\begin{array}{c}\text { Copies } \\
\text { supplied by } \\
\text { consortia }\end{array}$ & Percentage \\
\hline 2005 & 137600 & 74479 & 54 \\
\hline 2006 & 163895 & 91029 & 56 \\
\hline 2007 & 163760 & 88629 & 54 \\
\hline 2008 & 143755 & 83962 & 58 \\
\hline 2009 & 145802 & 84855 & 58 \\
\hline
\end{tabular}

Table 4: Percentage of copies supplied by consortia and total Rebiun requests (2005-2009)

The data show a small rise of 4 per cent in the number of copies supplied by consortia at the national level. This rate could be influenced by a greater capacity for buying e-journals and by the historical collections of library consortia.

In summary, statistical data provides evidence that the number of copy requests in academic libraries has been increasing slightly since 2005 . The analysis also suggests that differences between libraries within consortia and academic libraries outside consortia are increasing, both as suppliers and requesters, probably due to dissimilarities such as the level of research output, purchasing capacity or the size and relevance of their library collections. Furthermore, the implementation of new programmes for lending transactions within libraries of the same consortia will likely lead to an increase in transactions due to greater availability of information resources.

\subsection{Summary of the questionnaire on e-journals and ILDS service}

A questionnaire survey was conducted between May and June 2011 with the purpose of ascertaining the views of academic staff and researchers of the Faculty of Medicine, Autonoma University of Madrid (UAM). They were asked about their perceptions of the library's ILDS service, e-journal cancellations and their information retrieval patterns.

The questionnaire was delivered to a distribution list containing around 400 members of academic staff and researchers. The questionnaire consisted of 16 questions. The rate of response was 17 per cent with 65 respondents. The small cohort and low response rate means that conclusions must be tentative but nonetheless is a useful indicator of current perceptions. The questions appear in the Appendix.

-The first and second question investigated the demographic breakdown of respondents by medical disciplines and professional status (Table 5). This approach was considered helpful in order to assess the views of groups to the survey questions. 


\begin{tabular}{|l|r|r|}
\hline Professional status & Frequency & Valid \\
Percent \\
\hline Professors & 8 & 12,3 \\
Lecturers & 28 & 43,1 \\
Associate Professors & 12 & 18,5 \\
Postdoctoral & 11 & 16,9 \\
Researchers & 6 & 9,2 \\
PhD Students & 65 & 100,0 \\
Total &
\end{tabular}

Table 5: Respondents breakdown by professional status

In order to correctly identify the different methods used by researchers to access information the questions focussed on 'unmediated systems' and 'mediated systems'.

The 'Unmediated systems' available to access information were databases, e-journals and the catalogue of UAM library as well as Google. Researchers were asked to select them according a scale (1 more important to 4 less important).

Respondents chose the resources according to importance: databases, e-journals of UAM, Google and the UAM catalogue. The weighted mean of resources is shown in Figure 4

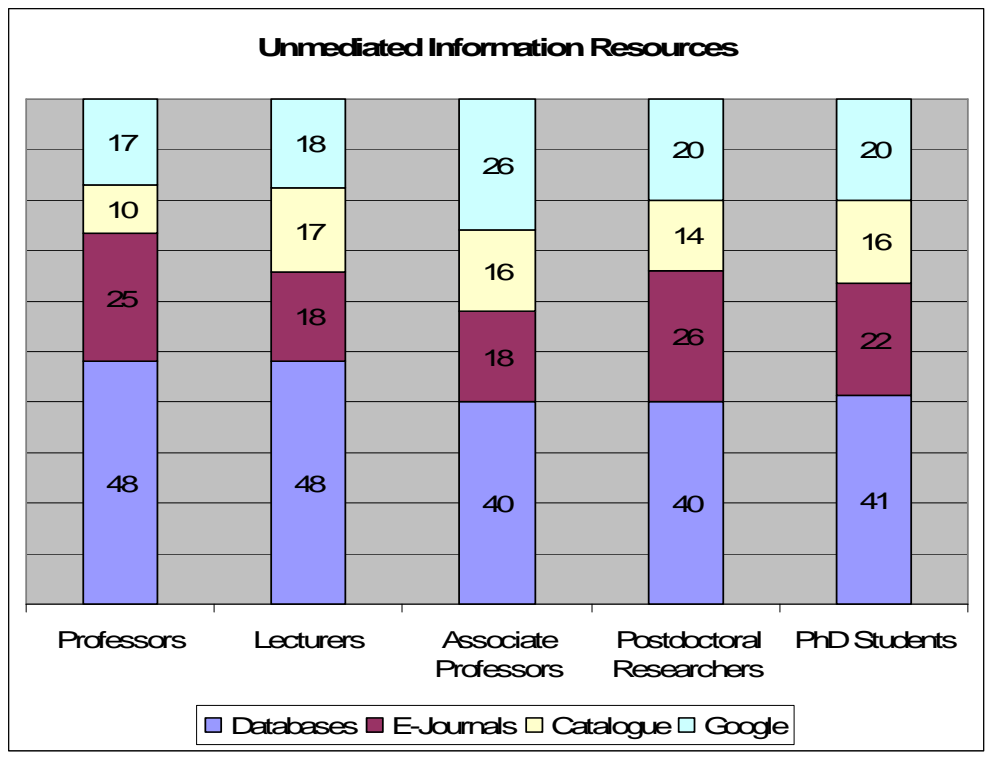

Figure 4: Weighted mean of unmediated resources selected in order of importance

The questionnaire also asked about the 'mediated systems 'used by researchers to obtain information (see Figure 5). The options were the ILDS service, requests to authors and requests to colleagues.

The ILDS service was chosen by most of faculty and researchers as the first resource, the only exception being associate professors at 33 per cent. ${ }^{19}$. Requesting information from authors and colleagues of external centres was also popular. An average 46 per cent of academic staff and researchers requested articles from colleagues and 58 per cent from authors.

\footnotetext{
${ }^{19}$ Associate professors are recognized specialists whose main activities are outside the university. Their duties are to contribute their knowledge and professional experience to university development. Interlending and document supply in the context of Spanish library consortia
} 


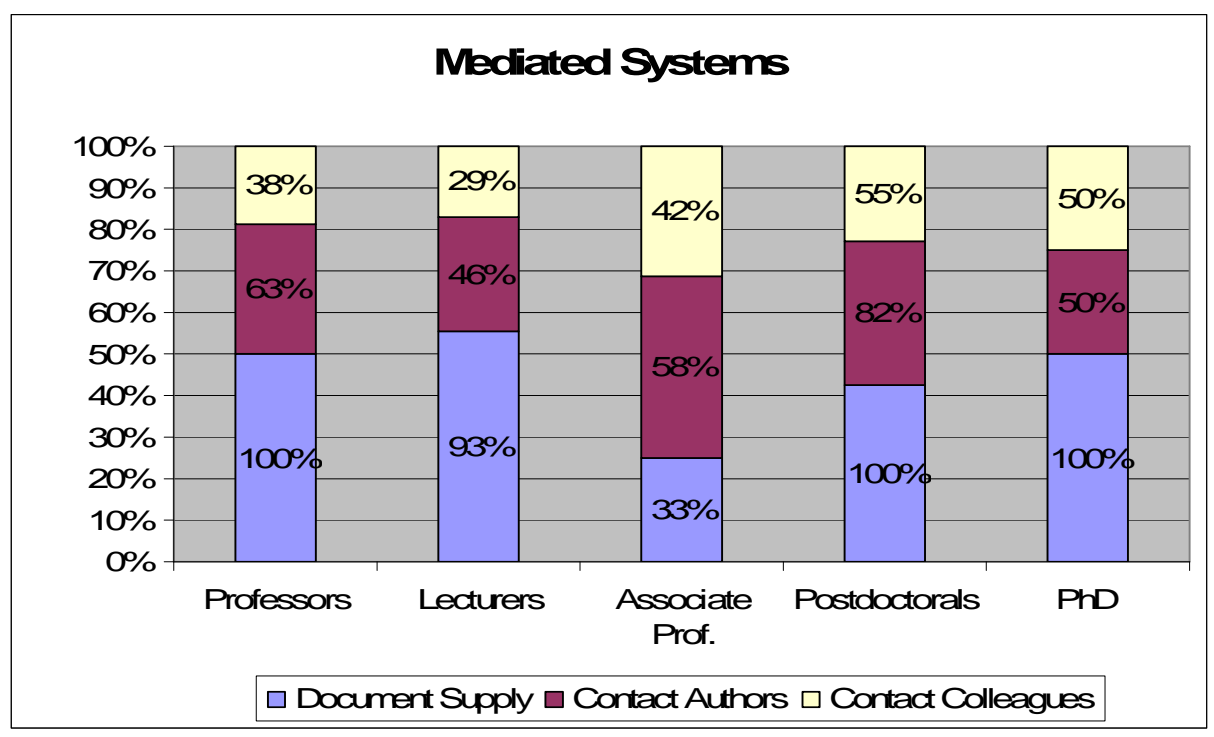

Figure 5: Mediated systems used to get information

Researchers were also asked whether in their opinion the ILDS service could substitute for ejournals cancellation. They could choose from following answers: never, low-use journals only and only if articles obtain in 48 hours through the ILDS service (see Figure 6).

As one would expect substituting ILDS for low use journals is fairly acceptable across all categories although faculty are more tolerant than postgraduate students and researchers. A significant minority would find a 48 hours ILDS an acceptable substitute.

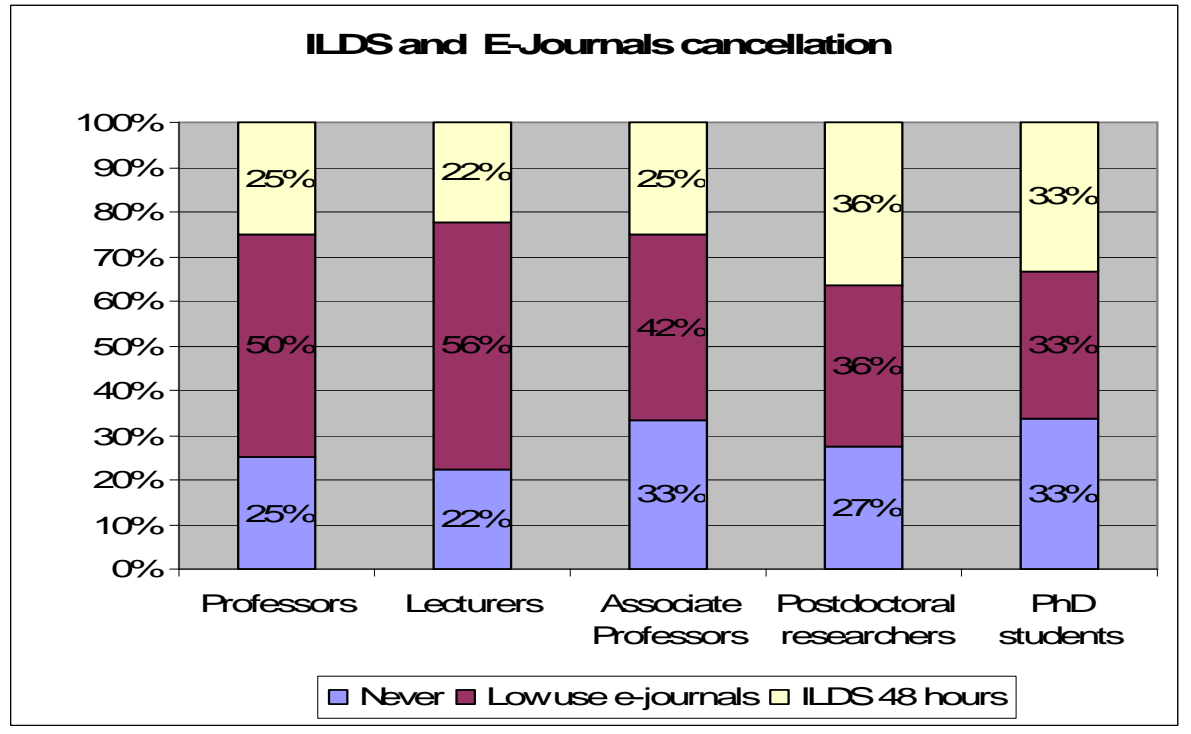

Figure 6: ILDS and e-journals cancellation

\section{CONCLUSION}

The main objective of this paper was to analyse the current environment of Spanish ILDS service in the context of Spanish library consortia, Big Deals and e-journal cancellations.

The regional model of Spanish library consortia based on autonomous communities prompted those academic libraries unable to form a consortium to set up a 'buying clubs' model. Libraries within consortia not only share information resources such as union catalogues, electronic resources, repositories and library services but also a solid structure of 
management and organization that allows them to improve their negotiating power for electronic licences and deal with changes.

A slight recovery of ILDS transactions of 5 per cent was recorded at national level. However, increasing differences were revealed between libraries within consortia and outside consortia, both as suppliers or as requesters, probably influenced by differences in research output, purchasing power and library collections. In addition, new lending initiatives within libraries of consortia will likely produce an increase in resource sharing transactions.

The other aim of this paper was to analyse the 'Big Deals' from an economic perspective. Figures shown that the market for journal publications is becoming more concentrated; a few publishers are marginalising smaller publishers as the 'Big Deals' take an increasing proportion of library budgets. The impact of the economic crisis with funding cuts and the increase of serial prices are forcing libraries to cancel journals previously thought of as untouchables in order to find the finance for consortia purchasing agreements. The strategy of Spanish library consortia is to extend participation to other partners within the same region, such as libraries of health services, research centres and even academic libraries from other regions. The paper also notes strategies adopted by other European countries for electronic resources purchasing through national licences, with special reference to Germany, a decentralised country like Spain, which has developed a comprehensive model of national licences.

Furthermore, the use of journals from 'Big Deals' was analysed. The results confirmed that the increase in digital information access fosters their use in general terms. However, as Térmens (2007) demonstrated the use of journals acquired as 'Big Deals' show a high degree of dispersion; 72 per cent were low use journals ( 5 per cent of total accesses) and a low degree of concentration of journals usage, 11 per cent of journals attracted high use ( 80 per cent of total accesses).

Finally, a questionnaire showed that the ILDS service is highly valued by researchers. The respondents identified what resources they used to access information, ranking in importance: databases, e-journals and Google. In addition the survey revealed that requesting articles from authors and colleagues is very popular among researchers. Substituting low use e-journals by the ILDS service was fairly acceptable to researchers. However, a significant minority thought a 48 hour ILDS service would be an acceptable substitute for e-journals.

Overall, it seems that consortia will likely continue to be valid in the future. However the Big Deal model of e-journal purchasing is no longer sustainable in the current economic crisis with journal prices rising and funding cuts. Libraries should coordinate their efforts to force publishers to be more flexible in the licensing of e-journals. Otherwise, the negative outlook for the future could be that libraries lose access to information. However the perspectives for ILDS service has started to improve after the impact of 'Big Deals' and the increasing number of documents in open access. One of the reasons has been that librarians have been aware of this shift, and have enhanced their practices and have taken into account the current needs of users. 


\section{REFERENCES}

Abad Hiraldo R., Anglada, L. (2010), "Los consorcios y las bibliotecas universitarias en España", Boletín de la ANABAD, no. 3, pp. 11-24.

Anglada, L. (2003), “Cooperación entre bibliotecas universitarias españolas y la experiencia del CBUC" in I Encontro das Bibliotecas do Ensino Supeiro. Available at:

http://www.cbuc.cat/cbuc es/content/download/891/4924/version/8/file/0312Portugal.pdf (Accessed 20 May 2011)

Anglada, L., Balagués, S., Comellas, N., Miranda, M.J., Reoyo, S., Ros, R., Tort, M. (2010), "Los consorcios como instrumentos de cooperación bibliotecaria: la experiencia del CBUC" Boletín de la $A N A B A D$, no. 3, pp. 25- 37.

Baena Díaz, C. (2010), "El Consorcio de Bibliotecas Universitarias de Andalucía (CBUA): 10 años avanzando juntos" Boletín de la ANABAD , no. 3, pp. 61-74.

Bevan, S., Dalton, P. and Conyers, A. (2005), "How usage statistics can inform national negotiations and strategies. Serials: The Journal for the Serials Community, vol. 18, no. 2, pp. $116-123$

Conferencia de Rectores de las Universidades Españolas, CRUE (2010), La universidad española en cifras. Available at: http://www.crue.org/Publicaciones/UEC.html (Accessed 20 May 2011)

España. Ministerio de Educación (2011), Datos y cifras del sistema universitario español: curso 2010/2011 [Data and figures of the Spanish higher education system: course 2010/2011]. Available at:

http://www.educacion.gob.es/dctm/ministerio/educacion/universidades/estadisticasinformes/novedades/2011-datos-cifras-10-uv.pdf?documentId $=0901 \mathrm{e} 72 \mathrm{~b} 809384 \mathrm{a} 4$ (Accessed May 2011)

Fernandez-Villaverde, J. and Ohanian, L. (2010), "The Spanish crisis from a global perspective", Documentos de trabajo (FEDEA) no. 3. Available at: http://www.fedea.es/pub/papers/2010/dt2010-03.pdf (Accessed 12 June 2011)

Frazier, K. (2005), "What's the Big Deal?” The Serials Librarian, vol. 48, no. 1, pp. 49-59.

Giordano, T. (2002), "Library consortium models in Europe: a comparative analysis" Alexandria, vol. 14, no. 1, pp. 41-52

Joint Information Systems Committee. (JISC) (2009), JISC Collections . Available at: http://www.jisc.ac.uk/whatwedo/services/jisccollections.aspx (Accessed 11 June 2011)

Joint Information Systems Committee. (JISC) (2011), “Transition in challenging times: an annual review of the work of JISC collections 2009-2010". Available at http://www.jisccollections.ac.uk (Accessed 12 June 2011)

López Ortiz de Artiñano, I. (2010), "El Consorcio Madroño: calidad y enfoque al usuario", Boletin de la $A N A B A D$, no. 3, pp. 39-50 
McGrath, M. (2009), "Prospects for document supply in the digital library". Paper presented at the $11^{\text {th }}$ Interlending and Document Supply Conference in Hannover, Germany, 20-22 October. Available at:

http://www.ilds2009.eu/fileadmin/user_upload/Full_text/ILDSvortraegeMike_McGrath1pdf.pd $\underline{\mathrm{f}}$ (Accessed 12 May 2011)

Martín Rodríguez, F. (2010), "BUCLE bibliotecas universitarias de Castilla y León". Boletin de la $A N A B A D$, no. 3, pp. 75-82.

Millor Rego, V. (2010), "BUGalicia Consorcio de bibliotecas universitarias de Galicia" Boletin de la ANABAD, no. 3, pp.51-60

Pacios, A.R. and Ortiz-Repiso, V. (2010), "Libraries in the strategic plans of Spanish universities" Libri, vol. 60, no. 4, pp. 352-360

Rebiun. (2008), Manual de procedimiento de préstamo interbibliotecario. Available at http://www.rebiun.org/export/docReb/Manual_de_PIB_2010.doc (Accessed 28 June 2011).

Rebiun. (2009), Consultas y cálculos sobre datos e indicadores de las bibliotecas. Available at: http://estadisticas.rebiun.org/cuestionarios/indicadores/indicadores_main.asp. (Accessed 30

June 2011)

Rosemann, U. and Brammer, M., (2010), "Development of document delivery by libraries in Germany since 2003”. Interlending \& Document Supply, vol. 38, no. 1, pp. 26-30.

Schöpfel, J. and Gillet, M.J., (2011), “A review of interlending and document supply in France: 2010”. Interlending \& Document Supply, vol. 39, no. 2, pp. 76-83.

Térmens , M. (2007), La Cooperació bibliotecària en l'era digital. Consorcis i adquisitions de revistes a les biblioteques universitàries catalanes [thesis]. Barcelona: Universitat de Barcelona. Available at : http://hdl.handle.net/10760/10813

(Accessed April 2011).

Térmens, M. (2008), "Looking below the surface: the use of electronic journals by the members of a library consortium" Library Collections, Acquisitions, and Technical Services, vol. 32 , no. 2 , pp. $76-85$

Turner, R. (2005), “Hidden costs of e-journals” Serials Librarian, vol. 48, no. 1, pp. 215-228

Urbano, C., Anglada, L., Borrego, A., Cantos, C., Cosculluela, A., Comellas, N. (2004), "The use of consortially purchased electronic journals by the CBUC (2000-2003)". D-Lib Magazine, vol. 10, no. 6, Freely available at: http://www.dlib.org/dlib/june04/anglada/06anglada.html (Accessed 25 May 2011) 


\section{Appendix \\ The questionnaire}

Question 1: Which discipline are you working in?

Anatomy

Biochemistry

Surgery

Pharmacology

Physiology

Internal Medicine

Obstetrics and Gynaecology

Pathology

Pediatrics

Psychiatry

Question 2. What position has you at the university?

Professor

Lecturer

Associate professor

Postdoctoral researcher

$\mathrm{PhD}$ student

Question 3. Have you used the ILDS service of the Library of Medicine?

If the answer is NO, please go to Question number 9.

Question 4. How have you heard about the ILDS service?

Web of the library

Library staff

Library marketing

Training courses

Others

Question 5. How many requests do you make to the ILDS service annually?

$1-2$ requests annually

3-5 requests annually

$6-9$ requests annually

$10-15$ requests annually

+20 requests annually

Question 6. Are you satisfied with the ILDS service?

Very satisfied

Satisfied

Doubtful

Dissatisfied

Very dissatisfied

Question 7. If you are satisfied with the ILDS service say why

The requests are received promptly

Documents are received in electronic format

I can know the requests situation

I can request articles from databases

Library staff is efficient

Others 
Question 8. If you are dissatisfied with the ILDS service say why

Requests are received late

Requests form is confused

The quality of electronic documents is poor

Library staff is not efficient

Others

Question 9. How long is an acceptable time to wait for requests?

2 working days

3 working days

4 working days

5 working days

Anytime

Question 10. Besides ILL, do you look for documents in any of these resources?

(Give an order 1/4)

Databases (PubMed, ISI Web of Knowledge, IME...)

Electronic journals of UAM

Catalogue UAM

Google

Question 11. To some extent, your information needs are fulfilled by the resources of the library UAM?

My needs are completely fulfilled

My needs are quite fulfilled

My needs are partially fulfilled

My needs are slightly fulfilled

My needs are insufficiently fulfilled

Question 12. Do you use external resources to find research documents?

Contact to authors of research documents

Contact to colleagues of other research centres

I don't use external resources

Others

Question 13. Are there publications in your research field that are not available to you?

Yes (Please give the titles)

No

Question 14. To some extent the ILDS service could substitute for e-journals cancellation?

Never

Low use journals

If I receive the articles in 2 days working

Others

Question 15. What do you think about the existence of two independent library nets in the autonomous community of Madrid (CAM)?

[We use 'consortia' to simplify the question to researchers although technically 'the Committee of the Health Library "Lain Entralgo" is not a consortium but rather a network of hospital libraries of the Autonomous Community of Madrid.\}

The Madroño consortium of public academic libraries of CAM

The Committee of the Health Library "Lain Entralgo"

Question 16. What would be your suggestion for improving the ILDS service and information services of the Library of Medicine UAM? 